\title{
A Public Health Model and Framework to Mitigate the Impact of Orphans and Vulnerable Children Due to HIV/AIDS
} in Cameroon

\author{
Dickson Shey Nsagha ${ }^{1}$, Ngowe Ngowe Marcelin ${ }^{2}$, Jules Clement Nguedia Assob ${ }^{3}$, \\ Anna Longdoh Njundah ${ }^{4}$ \\ ${ }^{1}$ Department of Public Health and Hygiene, Faculty of Health Sciences, University of Buea, Buea, Cameroon \\ ${ }^{2}$ Department of Surgery, Obstetrics and Gynecology, Faculty of Health Sciences, University of Buea, \\ Buea, Cameroon \\ ${ }^{3}$ Department of Biomedical Sciences, Faculty of Health Sciences, University of Buea, Buea, Cameroon \\ ${ }^{4}$ Department of Medical Laboratory Sciences, Faculty of Health Sciences, University of Buea, \\ Buea, Cameroon \\ Email: "nsaghads@hotmail.com,
}

Received 2 October 2013; revised 2 November 2013; accepted 9 November 2013

Copyright (C) 2014 by authors and Scientific Research Publishing Inc.

This work is licensed under the Creative Commons Attribution International License (CC BY).

http://creativecommons.org/licenses/by/4.0/

(c) (i) Open Access

\section{Abstract}

UNICEF, UNAIDS and USAID developed a global strategic framework to guide responses to care and protect orphans and other vulnerable children in the context of HIV/AIDS. In the developing world, about 132 million people have lost one or both parents due to the AIDS pandemic and 25 million children have been orphaned by HIV/AIDS in 2010. The HIV prevalence in Cameroon is estimated at $5.1 \%$. As of 2010, there were 304,000 deaths due to AIDS in Cameroon. Out of 1,200,000 orphans and vulnerable children in Cameroon in 2010, 300,000 were AIDS orphans. The HIV/AIDS burden impacts child survival, growth and development in the traditional African setting. With so many orphans in the population, along with many vulnerable children, strategies must be developed to respond more effectively to their critical needs. This study provides a model for OVC care and support in Cameroon. The model was developed out of extensive work using a participatory approach involving traditional, administrative and health stakeholders on OVC in Yaounde I and Yaounde VI Councils, Nanga Eboko Health District, Isangelle, Ekondo Titi, and Bafaka-Balue communities in Cameroon. Consultancy services with PLAN Cameroon, the Pan African Institute for Development-West Africa coupled with facilitation of many training workshops on OVC with Save the orphans Foundation, the Ministry of Social Affairs, and the Ministry of Public Health and work-

\footnotetext{
"Corresponding author.
} 
ing with the National AIDS Control Committee. The essential components of a holistic framework for the care of OVC have been identified. A public health model for the care of OVC and a mechanism for their identification and a referral system for testing OVC for HIV are proposed. Through this model, a mechanism for the effective holistic care of OVC and collaboration is enhanced.

\section{Keywords}

Orphans; Vulnerable; Children; HIV; AIDS; Public Health Model; Cameroon

\section{Introduction}

HIV and AIDS have created humanitarian and developmental crisis of unprecedented scale in developing countries where about 132 million people have lost one or both parents due to the pandemic and 25 million children have been orphaned by HIV/AIDS in 2010 [1]. Children of the world are innocent, vulnerable, dependent and are curious, active and full of hope. Their time should be one of joy, peace, playing, learning and growing [2]. More than two decades into the AIDS pandemic, a cure for AIDS has not yet been found and the negative impact of adult AIDS mortality on child welfare has been potentially massive [2]. Moreover, the impact of HIV and AIDS on rural livelihoods is insidious [3]. There is a fear that OVC will obtain less education, thereby worsening their own life chances, as well as the long-term economic prospects of the countries in which they reside [2] [3]. UNICEF [4] indicated that poverty contributes to low school attendance, low completion rates and low learning outcomes. Similarly, Curley and associates [5] argued that it is difficult to obtain an education if children live in poverty and lack resources and access to opportunities, although education is a key factor to overcome poverty and diseases.

In Cameroon, young women represent 7 in 10 of all youths aged 15 - 24 who are HIV infected. There are six new HIV infections per hour, approximately 141 per day, 4276 every month, and 51,315 per year [6]. The death toll from AIDS continues to rise. In 1995, 7900 people died from AIDS-related conditions; in just five years, the annual number rose to 25,000 in 2000 in the country. More than 34,000 deaths were projected in 2010. AIDSrelated deaths profoundly affect families, which often are split up and left without any means of support. Similarly, the loss of many people in their prime working years harms the economy. Businesses are adversely affected due to the need to recruit and train new staff. Health and social service systems suffer from the loss of health personnel, teachers, and other skilled workers. The number of children orphaned by AIDS-children under age 18 who have lost one or both parents to AIDS has increased dramatically, rising from 13,000 orphans in 1995 to 304,000 in 2010 [6]. By 2020, this number is projected to rise to 350,000. Children orphaned by AIDS represented about 25 percent of Cameroon's total 1,200,000 orphans in 2010 [6]. Providing appropriate support and care for OVC in Cameroon poses challenges for both families and society. Many OVC live outside of family support, and many are marginalised, stigmatised, and discriminated against. Consequently, they are exposed to harmful conditions such as lack of schooling, illiteracy, begging, pedophilia, juvenile delinquency, prostitution, and the transmission of HIV and other sexually transmitted infections [6]. A projection of the OVC burden in Cameroon from 1995 to 2020 is shown in Figure 1.

\section{Institutional Care of OVC in Orphanages Compared with Community Integrated Care}

The integrated care of orphans and other disadvantaged children in their natural environment in African settings is an old practice but this is different from institutional care of OVC where community link is absent. With the advent of HIV and AIDS and resultant deaths, the number of OVC has increased beyond a rate which the traditional African society cannot cope [7]. It is important that OVC live in their natural environment, hence the need to strengthen the capacity of families and communities to provide quality family-based care and support for OVC. The emerging consensus of opinion is that extended families and communities are the first line of defense in the orphan crisis and that families are almost always the best place for the child. Primary interventions should be centered on building the capacities of families to care for OVC. Residential orphan care is the least desirable option for children because orphan care institutions are inherently anti-community. As a result, institutional care is increasingly under 


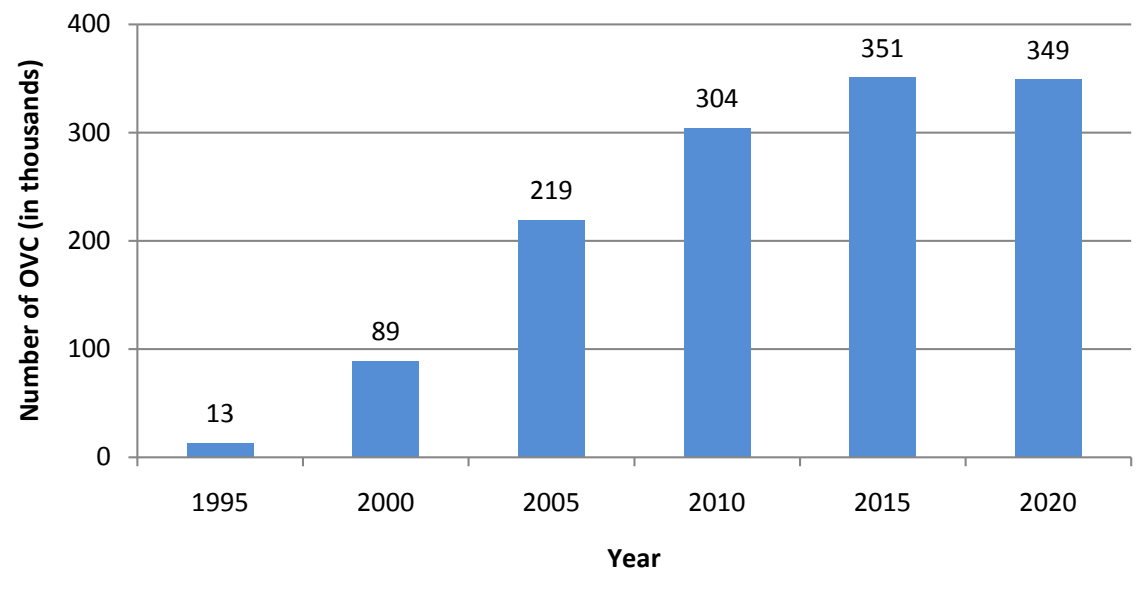

Figure 1. Projections of Children under 18 years orphaned by AIDS in Cameroon from 1995-2020 [6].

scrutiny and has been branded the last resort in a spectrum of interventions for OVC care [8]. For the purpose of developing this model, orphans are defined as children below the age of 18 who have lost one or both parents. A child made vulnerable by HIV/AIDS is below the age of 18 and meets one or more of the following criteria: has lost one or both parents/caregivers, has a chronically ill parent/caregiver, lives in a household where in the past 12 months at least one adult died or was seriously ill for an extended period of time, lives outside of family care (i.e. lives in an institution or on the streets), faces many problems (increase in poverty due to death of parents, loss of family and identity, lack of adequate adult support, increased risk of labour and sexual exploitation, fewer opportunities for education, loss of access to health care because of poverty, poor nutrition and malnutrition, and homelessness and vagrancy).

The integrated care of OVC constitute a major part of the UN Convention on the Rights of the Child [9] and the health-related Millennium Development Goals [10]. The integrated care approach helps OVC to cope with the social stigma of the disease and its economic consequences and adopts to their natural environment. Cameroon's first strategic plan on HIV and AIDS started in 1986 but it was not until 2006 that OVC were integrated into the policy with assistance from the Global Fund to Fight AIDS, Tuberculosis and Malaria [7]. The Government of Cameroon is committed to the integrated care of OVC as demonstrated by the ratification of many treaties including the UN Convention on the Rights of the Child [7].

In Africa, a large number of children do not live with their biological parents and are not raised by them; they are often fostered by the extended family. In Senegal, for example, child fostering is very common as $25 \%$ of children under age 15 do not live with their biological parents and 35\% for children of the 10 - 14 age group [11]. In Cameroon, the proportion of foster children is estimated at 22\% [12]. The placement of children within the kinship network and through connections is a long-standing and frequent practice in Africa. Thus, many children, when they become orphans, did not necessarily live with their biological parents. Even if a child lives with his or her biological parents and if one of them dies, he or she may not be considered an orphan because the traditional rules governing African societies facilitate the care of these children in particular through the movement of these children within the kinship systems. Locoh [12] pointed out that: "the care of related children has always been a means to handle health crises and to protect children if their parents die. This is the case with the AIDS pandemic. Grandparents-but also uncles, aunts, and older siblings-are in the front line to assume the care of orphans. The movement of children between various related households is not restricted to orphans. It is a very common practice, which makes the child part of the extended family circle and not exclusively raised by his or her biological parents". This model seeks to provide an integrated community mechanism for the care of OVC in Cameroon.

\section{Methods Used for Developing the Public Health OVC Model}

Through a participatory approach involving traditional rulers, administrative authorities and health stakeholders, the lead author has extensively worked on OVC in Yaounde I and Yaounde VI Councils [13] [14], Nanga Eboko Health District, Isangelle and Ekondo Titi Health Areas [7], and Bafaka-Balue community [15]. Consultancy services with PLAN Cameroon and the Pan African Institute for Development-West Africa coupled with facili- 
tation in many training workshops on OVC with Save the orphans Foundation, Ministry of Social Affairs, Ministry of Public Health and the experience working with the National AIDS Control Committee has been the bases for developing this OVC public health model for Cameroon. We also used the guidelines for the standard operating procedures for implementing social care for orphans and vulnerable children in the Kingdom of Cambodia [16].

\section{Results and Discussion}

\subsection{The Theoretical Framework for the OVC Model}

UNICEF, UNAIDS and USAID [17] developed a global strategic framework to guide responses to issues facing OVC. This shared framework was intended mainly to outline the priority actions needed to reduce vulnerability and the impact of orphanhood. The key principles of this global strategic framework which the government of Cameroon adopted include:

Ensuring that all activities are consistent with human rights principles as laid out in the Convention on the Rights of the Child, five key strategies to guide and direct responses to the needs of OVC, seven elements of programming guidance intended for those carrying out specific local programmes and monitoring and evaluation framework, including an agreed set of core national-level indicators [17].

Strengthen the capacity of families to protect and care for OVC by prolonging the lives of parents and providing economic, psychosocial and other support. This may be done in a number of ways including social protection, economic strengthening, psychosocial support, supporting carers succession planning, prolonging the lives of HIV positive parents and strengthening young people's own life skills [17].

Mobilize and support community-based responses. This strategy outlines key elements of community mobilization including engaging local leaders, enabling local communities to talk more openly about HIV and AIDS, organising and supporting cooperative activities and providing and supporting community care for children and young people without any family support [17].

Ensure access for OVC to essential services, including education, health care, and birth registration. Key services for OVC include education, birth registration, health, nutrition, water and sanitation, judicial protection and placement services for children and young people without family care [17].

Ensure that governments protect OVC through improved policy and legislation and by channelling resources to communities. This strategy includes ensuring that governments develop policies, strategies and action plans to guide national responses, enhancing government capacity, ensuring that resources reach local communities, ensuring that each country has a supportive legal framework and establishing mechanisms to ensure information exchange [17].

Raise awareness to create a supportive environment for children affected by HIVand AIDS. This strategy includes conducting a situation analysis, tackling stigma, silence and discrimination and strengthening and supporting community mobilisation efforts at community level. The global framework outlined above provides seven elements of guidance for those working on local OVC programmes (Table 1) [17].

\subsection{The Cameroon Decentralised Health Care System in the Context of the Fight against HIV/AIDS}

Cameroon is undergoing a demographic transition with about $50 \%$ of the population living in urban areas. Administratively, the country is divided into 10 regions headed by governors. Each region is divided into divisions, divisions into subdivisions and subdivisions into districts. Yaoundé is the administrative capital while Douala is its economic capital. The average income per capita over the last five years ranges from US\$ 600 - 650 [18]. The Ministry of Public Health co-ordinates all health services in the country. According to a Ministry of Public Health report in 2002, the health system is organised at three levels: central, intermediate and peripheral. The Central level has three reference health institutions of Category I and three of Category II. Of the Intermediary level are nine regional hospitals and affiliated health structures. Peripheral institutions are health districts. In 2002, there were 150 health districts and 1388 health centers [19]. Currently there are an estimated 174 health districts in Cameroon. Among the rest, some are under the auspices of private institutions and faith-based organizations (FBO). There is a national public health emphasis on preventive health services which are avail-ablethroughout the country to complete this national health structure. The national social insurance scheme in 
Table 1. Guidance key elements on OVC care as outlined in the global framework by UNAIDS, UNICEF and USAID in 2004.

\begin{tabular}{|c|c|}
\hline Key guidance elements on OVC care & Description of the key guidance elements \\
\hline $\begin{array}{l}\text { Focus on the most vulnerable children } \\
\text { and communities }\end{array}$ & $\begin{array}{l}\text { Not only children orphaned by AIDS. Programmes which target only those orphaned by } \\
\text { AIDS may increase stigma and discrimination. Care is also needed when using terms to refer } \\
\text { to children within a particular project. People from within a particular community are best } \\
\text { able to identify those children in greatest need. }\end{array}$ \\
\hline $\begin{array}{l}\text { Define community-specific problems } \\
\text { and vulnerabilities }\end{array}$ & $\begin{array}{l}\text { At the outset and pursue locally determined intervention strategies. When a new programme } \\
\text { starts in a particular community, it should be designed particularly to meet the needs of } \\
\text { orphans and other vulnerable children in that community. This will involve identifying } \\
\text { orphans and other vulnerable children and analysing the local situation facing them. } \\
\text { Community members should play a central role in all these processes. }\end{array}$ \\
\hline $\begin{array}{l}\text { Involve children and young people as } \\
\text { active participants }\end{array}$ & $\begin{array}{l}\text { In the response, children and young people should not be seen as a passive, powerless group } \\
\text { who need to be given help. They need to be allowed to actively participate in all aspects of } \\
\text { activities which affect them. }\end{array}$ \\
\hline $\begin{array}{l}\text { Give particular attention to the role of } \\
\text { boys and girls, men and women }\end{array}$ & $\begin{array}{l}\text { Address gender discrimination. For example, much of the burden of caring for vulnerable } \\
\text { children and sick adults falls on women. Also, vulnerable girls are more likely to drop out of } \\
\text { school than boys. Women are particularly vulnerable to HIV infection and are often excluded } \\
\text { from owning or inheriting land. }\end{array}$ \\
\hline $\begin{array}{l}\text { Strengthen partnerships and mobilise } \\
\text { collaborative action }\end{array}$ & $\begin{array}{l}\text { Working with other organisations can be a very good way of improving the activities being } \\
\text { carried out. }\end{array}$ \\
\hline $\begin{array}{l}\text { Link HIV and AIDS prevention } \\
\text { activities with care and support }\end{array}$ & $\begin{array}{l}\text { For people living with HIV and AIDS with support for vulnerable children. Such activities } \\
\text { include home-based care for people who are ill and HIV prevention. Greater linkages with } \\
\text { development activities in general avoid over-identification with HIV/AIDS and a risk of } \\
\text { increasing stigma and discrimination. }\end{array}$ \\
\hline $\begin{array}{l}\text { Use external support to strengthen } \\
\text { community initiative and motivation }\end{array}$ & $\begin{array}{l}\text { External support should strengthen and build on existing community initiative and } \\
\text { motivation. Great care should be taken to avoid undermining or replacing community } \\
\text { initiatives. }\end{array}$ \\
\hline
\end{tabular}

Source [17].

Cameroon does not cover the health service; patients have to pay for every aspect of services rendered [18].

\subsection{The Health Care System}

The Cameroon health care network has suffered tremendously within the 1990s when HIV and AIDS was difficult to cope with, ARV were expensive, social stigma was high and there were many misconceptions about the pandemic. HIV and AIDS have important implications for Cameroon for there is a direct negative impact, as it affects the HIV and AIDS MDG component and other health-related goals and there is an indirect impact on the efficiency of the labour force [7]. An anti-retroviral free drug distribution policy to assuage the problem of accessibility to ART is very important in order to prolong life and reduce mortality due to AIDS [7].

\subsection{HIV/AIDS Risk Groups in the Country}

The trends of HIV infection have been reported in various target groups of the population including commercial sex workers, long distance lorry drivers, uniformed officers and tuberculosis patients [18]. In some of these groups, the HIV prevalence has been as high as $40 \%-50 \%$. In one HIV study in specific subpopulations of Cameroon [20], a prevalence of $26.4 \%, 19.9 \%$ and $16.3 \%$ was respectively observed in female commercial sex workers, residents along the Chad-Cameroon petroleum pipeline and long distance truck drivers. In the same analysis, lower prevalence was recorded in health care personnel (5.2\%) and university students (3.8\%). These findings confirm the need for expanded prevention and care programmes for high risk groups of the community [18], hence reduction in AIDS deaths.

\subsection{Cameroon Government Interventions and Outcomes}

The first important government intervention against the HIV epidemic in Cameroon was the creation of the National AIDS Control Committee (NACC) in 1986, to coordinate AIDS programmes nationally. The World Health Organisation/Global Programme on AIDS (WHO/GPA) plan was first introduced in Cameroon in 1987, and in 1991 the NACC was made a branch of Preventive Medicine in the Ministry of Public Health [18]. The 
first Strategic Plan for Cameroon covered 2000-2005. This plan included the strategies for the prevention of the transmission of STI/AIDS with emphasis on women of childbearing ages, prevention of mother-to-child transmission and the prevention of HIV transmission through blood. The management of infected cases was enabled through the enhancing of access to treatment and care and programmes to protect and promote the rights of PLWHA were some of the strategies [18]. Furthermore, the promotion of research as well as strategies for the coordination of the programme throughout the national territory were established and implemented. The second national Strategic Plan for 2006-2010 focused on six aspects: universal access to HIV prevention in targeted groups; universal access to treatment for adults and children living with HIV; protection and support to AIDS orphans and vulnerable children (OVC); involvement of all stakeholders in the fight against HIV and AIDS; epidemiological surveillance and research promotion as well as the reinforcement, coordination and management of the programme, partnerships and the monitoring and evaluation of its implementation [18]. A model for the comprehensive care and protection of OVC in Cameroon is presented in Figure 2.

\subsection{The Multi-Sectorial Strategy to the Fight against HIV/AIDS}

The access to treatment and care has been mostly supported by the Cameroon Government, Global Fund for AIDS, Tuberculosis and Malaria (GFATM) and to some extent by other agencies. According to the Report by the National AIDS Control Committee in 2008 [21], the GFATM has supported this since 1st January 2005 and renewed it in February 2007 for a period of three years. The Clinton Foundation also supports second line ARV for adults and first and second line ARV for children. In December 2006, there were 28,403 patients on ARV and by December 2007 the number effectively on treatment had reached 45,605 (49.9\%), an increase by 61\%. About $6.2 \%$ had been lost either through death (2.2\%) or totally lost to follow-up (4.0\%). A similar trend has also been observed in paediatric cases with 1001 on ARV in December 2006 and 1700 by December 2007, an

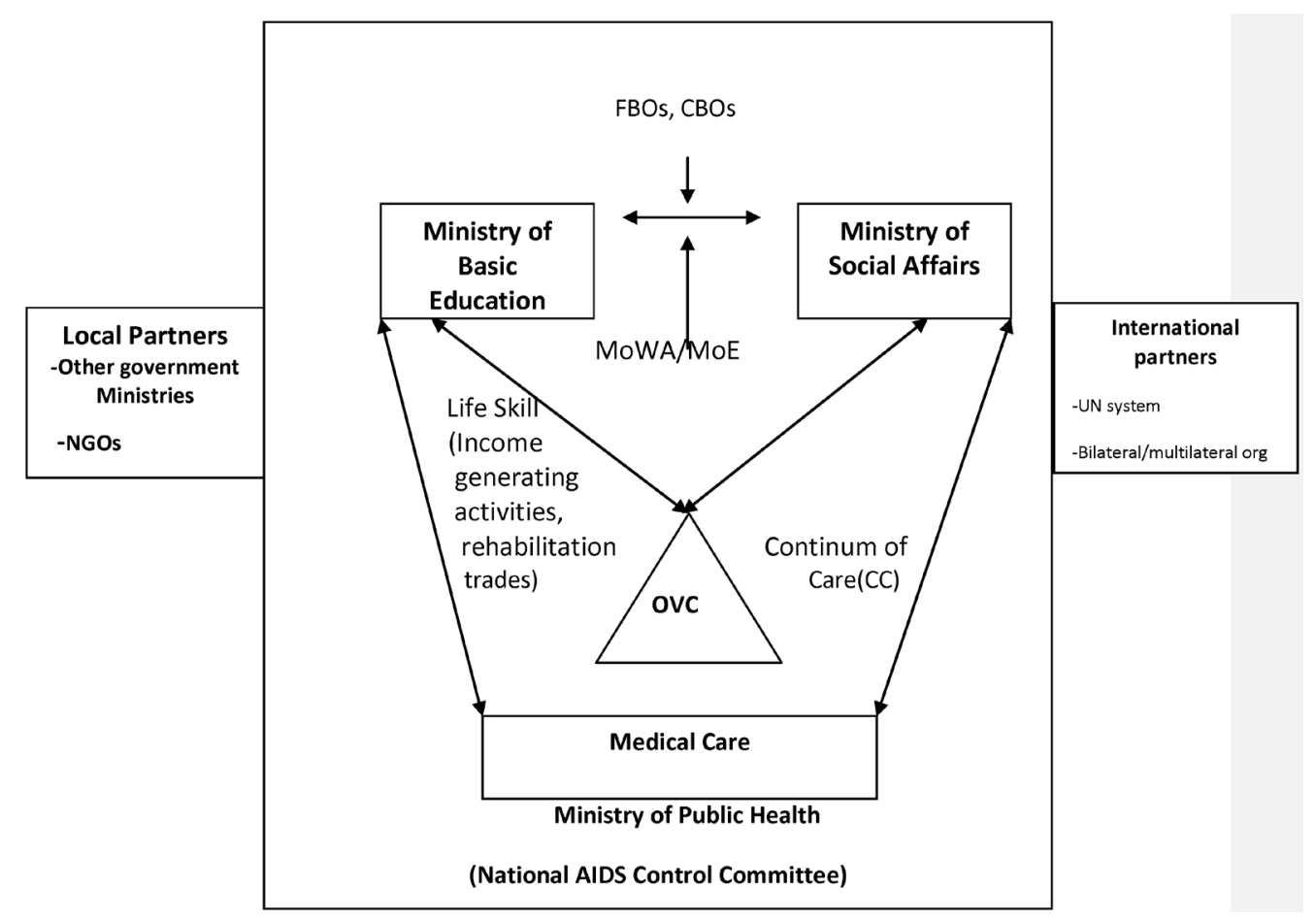

Figure 2. Model for the comprehensive care and protection of OVC in Cameroon. NGO = Non-Governmental organization; $\mathrm{FBO}$ = Faith-based organization; $\mathrm{CBO}=$ Community-based organization; MoWA = Ministry of women affairs; MoE = Ministry of Employment; Other government Ministries include Ministries of Agriculture \& Rural Development, Ministry of Economy, Planning and Regional Development, Ministry of Finance, Ministry of Higher Education, Ministry of Industry, Mines and Technological Development, Ministry of Justice, Ministry of Labour and Social Security, Ministry of Public Services and Administrative Reform, Ministry of Public Works, Ministry of Scientific Research and Innovation, Ministry of Secondary Education as well as the Children's Parliament. 
increase of approximately 70\% [18].

\subsection{Involvement of Stakeholders and Capacity Building for the Fight against HIV/AIDS}

Figures 3 and 4 show models for identifying OVC, care provision and HIV testing in Cameroon. The OVC program has involved various categories of stakeholders (Figure 3), assisting them technically and financially in anti-AIDS activities. For example in 2006, 130 associations of PLWHA were sponsored and in 2007 there were 101 sponsored. Religious organizations, to promote moral education also received financial support in 2007. Opinion leaders including political leaders, traditional chiefs, administrative authorities have been implicated, and the public sector (Government and private structures, firms, NGOs, International partners including WHO, UNICEF, UNAIDS, World Bank, CDC, French Cooperation, UNESCO, UNDP, CARE, GTZ, PLAN International etc.) have all collaborated in the achievement of success in the implementation of this plan. The role of the media cannot be overemphasized [18].

Epidemiological surveillance has been the notification of new cases (Figure 4). For example in 2006 there were 8569 new cases notified, compared to 10,625 new cases in 2007. The major research projects have covered: virological studies including resistance studies; prevention of mother-to-child transmission of HIV; clinical \& epidemiological research; social science aspects as well as Public health research. Some of the major institutions involved in the various arms of research include the National AIDS Control Committee, universities, the Institute Pasteur, the French National Agency for AIDS Research, CRESAR, CDC Atlanta, the Chantal Biya International Research Centre, and others. A lot of data is generated \& disseminated in various ways both nationally and internationally, some of which has been used to implement policy [18].

In order to ease patient monitoring and treatment, there has been marked capacity building (Figures 3 and 4 ) and recruitment of psychosocial staff (184 in 2005 and total of 508 by 2007); subsidized laboratory testing packages (for CD4 counts, full blood counts, fasting blood sugar and liver enzymes is one package that costs 3000Frs CFA-approximately \$7 USD) and health systems reinforcement through the provision of equipment to health institutions (spectrophotometers, flow cytometres, electronic counters etc.). Furthermore, in 2007, a nutritional support programme was implemented for which 120 personnel have already been trained [18].

\subsection{Protection and Support to OVC}

In 2006, taking into consideration all categories of OVC, there were 183, 523 identified for assistance by the na-

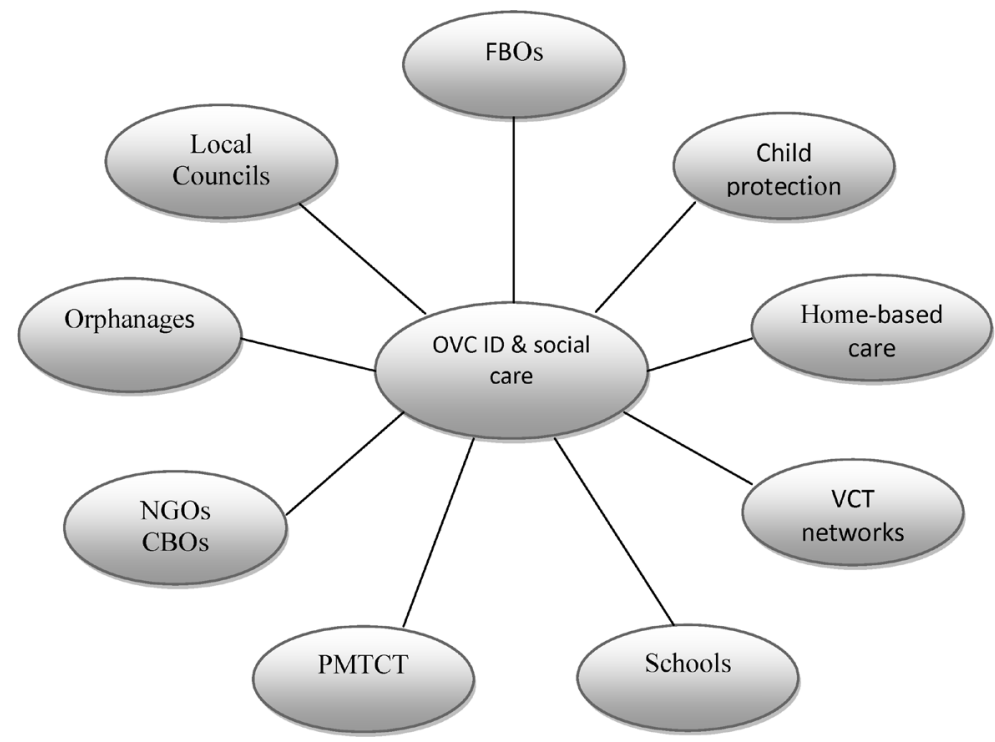

Figure 3. Sources for identifying and providing care to OVC in Cameroon. NGO = Non-governmental organization; FBO = Faith-based organization; $\mathrm{CBO}=$ Community-based organization; PMTCT = Prevention of mother-tochild transmission of HIV; VCT = Voluntary counseling and testing; OVC ID $=$ Orphans and vulnerable children identification. 


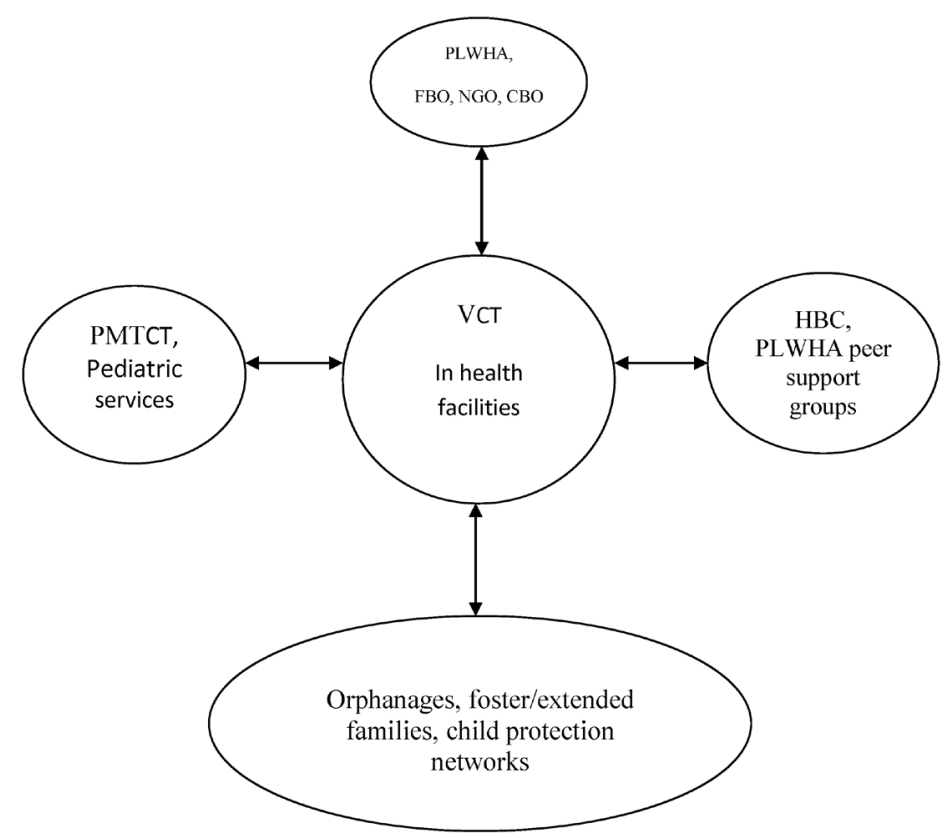

Figure 4. Referral Mechanisms for identifying and testing OVC for HIV in Cameroon, NGO = Non-governmental organization; FBO = Faithbased organization; $\mathrm{CBO}=$ Community-based organization; PMTCT = Prevention of mother-to-child transmission of HIV; VCT = Voluntary counseling and testing; HBC = Home based care; PLWHA = People living with HIV/AIDS.

tional AIDS Control Committee, of which assistance was provided to 25,643 (14\%). In 2007, assistance was given to 43,505 of them, an increase by $69.6 \%$. However, when AIDS orphans were examined, 12,776 and 28,319 (121.7\% rise) were respectively catered for in 2006 and 2007 [18].

\subsection{Parental Care and Support}

Orphans who have lost one or both parents suffer from psychosocial torture, while simultaneously bearing the family's economic responsibilities stemming from the loss of parental income and increased health care expenses [22]. Growing up without parental care and love deprives children of a family system of support because OVC rely on the extended family system to meet their individual and collective needs [23]. Parents have an essential role in providing an intellectual, emotional and self-esteem support to their young children. Without parents, children are devoid of the support and care which helps them to develop a positive concept of who they are and self-care instruction which helps to prepare them for success in adult life [2]. Whether OVC are HIV infected or not, stigma coupled with the ensuing ostracism is a big challenge. Stigma has terrible negative effects yet it is so clear that it has been considered an epidemic itself [24]. As a result of stigma, OVCs are often discriminated, a problem that further intensifies their psychological distress. A mixture of challenges like anxiety, grief, trauma, depression, stigma and discrimination make the wellbeing of OVCs' exceptional [25].

As indicated by Serey et al. [2], due to family poverty, OVCs need external support from NGOs and local communities; however, most people in the communities are also poor so they can only offer psychological support. OVCs needed food, accommodation, school material, birth certificates, will development to protect their property, clothes, vocational training and income generating activities in order to face the future with hope. OVCs need a long-term educational support with insurance of family's economic stability [2].

The necessity to enhance the capacity of the "extended family concept" to mitigate the impact of HIV and AIDS among OVC is very important. There is need to empower households headed by OVCs with income generating activities. Double orphans face difficult problems psychologically because there is no hope of where to revert to when everything is not fine; single orphans whose parents had separated face the same problem [7]. 


\subsection{Legal Support to OVC}

Birth registration is fundamental to the realisation of a number of rights and a number of practical needs including: providing access to health care, immunisation, ensuring that children enrol in schools, securing the child's right to a nationality at the time of birth or at a later stage [7]. Most births in Cameroon are not registered which hinder children including OVC from writing the final primary school examination as this is a main requirement. The Children's parliament in Cameroon may act as a mouth piece to fight for the legal rights of OVC if some of them become members of this parliament. In the guiding principle of the Cameroon National AIDS Control Committee, there is a strong political will and commitment in supporting the national and international NGOs to deliver services through the application of children-centered approach for OVC, Convention on the Rights of the Child, child involvement and gender equity. As pointed out by Serey et al. [2], OVC have to be involved in any decision-making forum and should be represented. By taking part in development activities, children often acquire skills and confidence that help them not only now but also in the future. The Cameroon Children's Parliament can effectively play this role.

\subsection{Education of OVC}

Primary education is free in public schools in Cameron, but pupils need some basic requirements for success. Education stands out significantly because it is the backbone of development. The relatively high national literacy rate in Cameroon was achieved before the adoption of the MDGs and primary level of education is now at 85\% making it possible for the country to attain MDG number 2 [26]. This is clearly evidenced in Cameroon’s Progressive National Primary Education Policy and the awareness on the importance of sending children to school particularly after independence in 1960. Net primary school enrolment increased from $73.6 \%$ at the MDGs baseline years to $75.2 \%$ in 2001 [27]. The government enhanced the increase enrolment into primary schools by eliminating primary school fees. The incorporation of HIV and AIDS lessons into the primary school curriculum can greatly contribute in fighting against the pandemic and giving the children a future with hope $[7]$.

The OVC need much assistance but the provision of schools with all school requirements for OVC would encourage school enrollment including acquisition of birth certificates for all children who need them and treating all sick children through signing of contracts with health institutions for periodic medical checks can greatly improve OVC living conditions and provide them a future with hope [7].

Nsagha and Thompson [7] have argued that the incorporation of HIV/AIDS lessons into the primary school curriculum will empower OVC to prevent themselves from HIV and nutritional programmes (lunch canteens) and the enhancement of foster families to provide food for OVC will build the capacity of the children and the families, which no doubt, is a major component of sustainability.

\subsection{Bilateral and Multilateral Cooperation}

The policy and political will of the government of Cameroon through the National AIDS Control Committee of the Ministry of Public Health is important to source for more funds to implement a nation-wide OVCs development scheme to address the pressing OVC needs of basic education, acquisition of birth certificates, health care, nutrition and income generating activities. The funding gap may be the most significant barrier which make it difficult for more funds to reach OVCs impact mitigation as revealed by the experience of the expenses in 2006 , 2007 and 2008 in Cambodia where only less than one percent of the funds went to social protection and social service, while a lot more funds were for care, treatment, prevention, programme management and administration [2].

Partnering with foreign bodies has boosted Cameroon's fight against HIV, as seen in the decrease in the cost of anti-retroviral drugs and increase free HIV screening over the years largely due to funding from the Global Fund to fight tuberculosis, AIDS and malaria [7]. This has helped the country to fight the pandemic by increasing the general life expectancy from 49.85 to 52.9 years and favouring economic growth since HIV is more prevalent in youths [27]. Partnership development to improve the quality of life of OVC is very important in child survival [9] [10] [27] [28]. At the local level, partnership with the Bafaka Balue Village Development Association and government ministries (Public Health, Basic Education, Social Affairs, Agriculture, Justice, Finance, Youths Affairs, External Relations, Fisheries, Livestock and Animal Industry, Higher Education, Em- 
ployment and Vocational Training, Small and Medium Size Enterprises, Forestry and Wildlife, Women Empowerment and the Family, Environment and Nature Protection, and Labour and Social Security) would be good [7]. At the international level, establishing strong and sustainable working collaborations with UNICEF, UNAIDS, WHO, UNESCO, ILO, Save the Children, bilateral and multilateral organizations, NGOs like PLAN International, CARE and the Global Action for Children can help solve OVC crisis [7].

\section{Conclusion}

This model that lays a lot of emphasis on the care of OVC in their natural environment needs to focus more on the social care through the provision of basic social needs and vocational rehabilitation. The psychological impact of HIV/AIDS including social stigma is enormous on many OVC and needs to be addressed as this affects their growth, development and survival. The quantification of stigma and stress is new research areas in OVC care [7].

\section{Acknowledgements}

We are grateful to the various organizations, the Ministry of Public Health, and the Ministry of Social Affairs for the exposure given to the lead author to work on OVC and the collaboration of the different communities. Mr. Zacharia Itambi of the Ministry of Public Health is thanked for technically editing the document.

\section{Contribution of Authors}

NDS conceived the model, draft the manuscript and substantially revised it. NNM, AJCN and NAL substantially revised the manuscript. All authors read and approved the manuscript.

\section{References}

[1] GAC (2010) Orphan and Vulnerable Children. Global Action for Children. http://www.globalactionforchildren.org

[2] Serey, S., Many, D., Sopheak, M., Sokkalyan, T., Sela, S.A., Chanravuth, L. and Sophal, K. (2011) Addressing the Special Needs of Orphans and vulnerable Children (OVC): A Case Study in Kien Svay District, Kandal Province, Cambodia. Journal of AIDS and HIV Research, 3, 43-50.

[3] Barnett, T. and Whiteside, A. (2006) AIDS in the 21st Century: Disease and Globalization. Palgrave Macmillan, London, 1-416.

[4] UNICEF (2007) A Human Rights-Based Approach to Education for All. United Nations Children’s Fund, New York, 39-41.

[5] Curley, J., Fred, S. and Han, K.C. (2010) Assets and Educational Outcomes: Child Development Accounts (CDAs) for Orphaned Children in Uganda. Children and Youth Service Review, 32, 1585-1590. http://dx.doi.org/10.1016/j.childyouth.2009.07.016

[6] National AIDS Control Committee (2010) The Impact of HIV and AIDS in Cameroon through 2020, 1-40.

[7] Nsagha, D.S. and Thompson, R.B. (2011) Integrated Care of Orphans and Vulnerable Children in the Ekondo Titi and Isangelle Health Areas of Cameroon. Journal of HIV/AIDS \& Social Services, 10, 161-173. http://dx.doi.org/10.1080/15381501.2011.572740

[8] Aubourg, D.E. (2004) Expanding the First Line of Defense: Community-Based Institutional Care for Orphans. International Conference on AIDS, Bangkok, 11-16.

[9] United Nations General Assembly (1990) Convention on the Rights of the Child, Publications and Information on the Work of the United Nations Children’s Fund and Its Advocacy for Children's Rights, Survival, Development and Protection. www.unicef.org/crc

[10] WHO (2009) Millennium Development Goals. http://www.who.int

[11] Audemard, C. and Vignikin, K. (2011) Orphans and Vulnerable Children Due to HIV/AIDS in Sub-Saharan Africa. http://www.ceped.org/cdrom/orphelins_sida_2006/en/biblio/index.html

[12] Locoh, T. (2002). Fertility Decline and Family Changes in Sub-Saharan Africa. The Journal of African Policy Studies, 7, 17-48.

[13] Njom-Nlend, A.E., Mbessa-Ayissi, J.P. and Nsagha, D.S. (2007) Approche Méthodologique pour le Recensement des Orphelins et Enfants Vulnérables en Milieu Urbain au Cameroun (Yaoundé 1 et Yaoundé 6). 4th Conférence Franco- 
phone, Paris, 29-31 Mars 2007.

[14] Njom-Nlend, A.E., Mbessa-Ayissi, J.P., Nsagha, D.S., Talom, K., Dongmo, H.E.T., Elong, N., Bela, M. and Tjeega, F. (2007) Profil Sociodémographique des Orphelins et Enfants Vulnérables en Milieu Urbain: Le cas de la Ville Yaoundé. 4th Conférence Francophone, Paris, 29-31 Mars 2007.

[15] Nsagha, D.S., Njunda, A.L., Kamga, H.L., Assob, N.J.C. and Mokube, J.A. (2013) The Epidemiology of Orphans and Vulnerable Children Due to HIV/AIDS in an Integrated Community Care Scheme in Bafaka Balue, Ndian Division, Cameroon. Social Aspects of HIV/AIDS Research Alliance, in press.

[16] National Center for HIV/AIDS Dermatology and STD (2007) Standard Operating Procedures for Implementing Social Care for Orphans and Vulnerable Children. Kingdom of Cambodia, 1-29.

[17] UNICEF, UNAIDS and the Future Group (2004) National Responses to Orphans and Other Children in sub-Saharan Africa-The OVC Programme Effort Index 2004, September; and Demographic and Health Surveys, 2006.

[18] Mbanya, D., Sama, M. and Tchounwou, P. (2008) Current Status of HIV/AIDS in Cameroon: How Effective Are Control Strategies? International Journal of Environmental Research and Public Health, 5, 378-383. http://dx.doi.org/10.3390/ijerph5050378

[19] Ministère de la Santé Publique (2002) Cadre conceptuel du DIS viable. Cameroun, 1-12.

[20] Musoko, J.J., Macauley, I.B., Zoungkanyi, A.B., Bella, A., and Koulla-Shiro, S. (2007) Human Immunodeficiency Virus Infection and Associated Factors among Specific Population Subgroups in Cameroon. AIDS and Behaviour, 9294-9298.

[21] Comité National de Lutte Contre le SIDA: Rapport Annuel d'Activités du Programme National de Lutte Contre le SIDA, Groupe Technique Central, 2007; Yaoundé, Mars 2008.

[22] Deters, L. (2008) Orphans and Vulnerable Children in Ghana A Contextual Analysis: ECCD Stakeholders Adapting the Safety Net. Master of Arts in International Educational Development at Teachers College, Columbia University, $1-21$.

[23] Turnbull, A. and Turnbull, R. (2001) Self-Determination for Individuals with Significant Cognitive Disabilities and Their Families. JASH, 26, 56-62.

[24] Nyblade, L., Pande, R., Mathur, S., MacQuarrie, K., Kidd, R. and Banteyerga, H. (2007) Disentangling HIV and AIDS Stigma in Ethiopia, Tanzania and Zambia. http://www.icrw.org/docs/stigmareport093003.pdf

[25] Mbugua, T. (2004) Responding to the Special Needs of Children: Educating HIV/AIDS Orphans in Kenya. Child Education, 80, 304-309. http://dx.doi.org/10.1080/00094056.2004.10521276

[26] Cameroon (2014) Achieving the MDGs. HPI 7/1/2009 English Full Document: The Millennium Development Goals (MDGs). http://www.healthpolicyinitiative.com/index.cfm?ID=publications

[27] Tsounkeu, M. (2009) The Millennium Development Goals in Cameroon: How Far from the Target in 2005. http://www.indexmundi.com/cameroon/millennium-development-goals.html

[28] Cameroon, Ministry of Public Health (2009) Cameroon National AIDS Control Committee. Evaluation of the Data on the Management of Orphans and Vulnerable Children: January 2006-December 2007. 1-132.

http://www.minsante.cm 